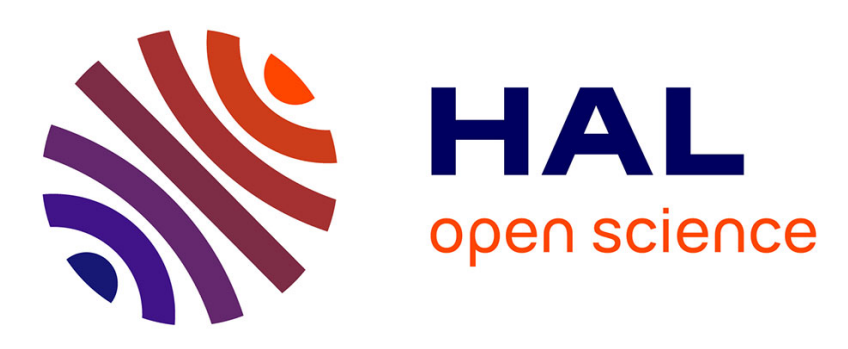

\title{
Efficacy of intra-articular hyaluronic acid injection in knee osteoarthritis in everyday life
}

Julie Quilliot, Marion Couderc, Charlotte Giraud, Martin Soubrier, Sylvain Mathieu

\section{- To cite this version:}

Julie Quilliot, Marion Couderc, Charlotte Giraud, Martin Soubrier, Sylvain Mathieu. Efficacy of intra-articular hyaluronic acid injection in knee osteoarthritis in everyday life. Seminars in Arthritis and Rheumatism, 2019, 10.1016/j.semarthrit.2019.02.001 . hal-02090318

\section{HAL Id: hal-02090318 https://hal.science/hal-02090318}

Submitted on 28 Nov 2019

HAL is a multi-disciplinary open access archive for the deposit and dissemination of scientific research documents, whether they are published or not. The documents may come from teaching and research institutions in France or abroad, or from public or private research centers.
L'archive ouverte pluridisciplinaire HAL, est destinée au dépôt et à la diffusion de documents scientifiques de niveau recherche, publiés ou non, émanant des établissements d'enseignement et de recherche français ou étrangers, des laboratoires publics ou privés. 
Efficacy of intra-articular hyaluronic acid injection in knee osteoarthritis in everyday life

Julie Quilliot, Marion Couderc, Charlotte Giraud, Martin Soubrier, Sylvain Mathieu

Rheumatology department. Gabriel Montpied Teaching Hospital. Clermont-Ferrand, France

Corresponding author: Sylvain Mathieu, Rheumatology Department, Gabriel Montpied Teaching Hospital, 58 Rue Montalembert, 63003 Clermont-Ferrand, France

Email: smathieu@,chu-clermontferrand.fr

In an article published in Seminars in Arthritis and Rheumatism, Maheu et al reminded us that intra-articular hyaluronic acid (IAHA) injections should be considered a therapeutic option for treating knee osteoarthritis (KOA) [1]. In this letter, we contribute data to support that conclusion. As previously reported, the widespread use of IAHA injections differs from the guidelines, because the literature indicates that IAHA efficacy is weak and often short-lived [2]. However, it is difficult to draw strong conclusions from existing data, because patients included in clinical trials are completely different from those treated in real life. Therefore, we assessed the effects of IAHA in everyday patients.

Our group of rheumatologists recruited 166 inpatients and outpatients with KOA treated with IAHA through a website (www.reseau-viscauvergne.fr). Baseline and follow-up assessments at 3 and 6 months after injections were completed by patients online. Assessments included visual analogue scale (VAS) pain and functional scores (Lequesne and KOOS index [3]). Patients were defined as responders, when they reported more than $50 \%$ improvement in the global VAS.

To compare the evolution of parameters over time, we assessed between-group differences with a repeated-measure analysis of variance (ANOVA), or a Friedman's test, when 
necessary, followed by a paired t-test or Wilcoxon test for within-group comparisons. Relationships between the proportion of responders and patient characteristics were tested with linear regression, logistic regression, or Chi2 tests, as appropriate, for quantitative and categorial parameters.

The mean age was $63.8 \pm 11.2$ years; the mean body mass index (BMI) was $30.0 \pm 6.2$ $\mathrm{kg} / \mathrm{m}^{2}$. Fifty-five patients had important $(>50 \%)$ space narrowing. At baseline, the mean pain VAS was $56.0 \pm 17.4 \mathrm{~mm}$, and the mean Lequesne and KOOS indexes were $9.5 \pm 4.2$ and $54.5 \pm 17.5$, respectively. Thirty per cent of patients received articular injections guided by radiography.

Three months after IAHA, 77 patients completed online surveys (Table 1). Compared to baseline, we found a significant improvement in the pain VAS, Lequesne index, and KOOS index. Of the 55 patients that reported improvement, 35 were considered responders. Responders were older than non-responders ( 66.5 years vs. 60.3 years; $p=0.01$ ), but they were similar in terms of $\operatorname{sex}(\mathrm{p}=0.41), \mathrm{BMI}(\mathrm{p}=0.66)$, number of injections $(\mathrm{p}=0.11)$, and radiological severity $(\mathrm{p}=0.52)$. A radiographic-guided injection was associated with a higher proportion of responders $(16 / 25$ vs. $14 / 37, \mathrm{p}=0.03)$.

We obtained 93 online surveys at 6 months. Compared to baseline, we found a significant improvement in all parameters, except for pain (Table 1). Responders and non-responders were similar in terms of age, sex, BMI, number of injections, radiological severity, and use of radiographic guidance.

Presumably, the questionnaire was easier to complete for patients that experienced an improvement. Therefore, our results might be overestimated. However, in the extreme hypothesis that all patients that dropped out of the survey failed to improve with IAHA, the 3- 
month and 6-month improvement percentages would have been $33 \%(55 / 166)$ and $43 \%$ (72/166), respectively, which were acceptable improvement rates.

Our study results showed that IAHA injections seemed to be an efficient treatment for KOA, even in everyday practice, which reinforces the conclusion of Maheu et al.

Table 1. Evolution of parameters over time after intra-articular hyaluronic acid injections for treating knee osteoarthritis

\begin{tabular}{|c|c|c|c|c|}
\hline \multirow[t]{2}{*}{ Parameters } & \multicolumn{2}{|c|}{$\begin{array}{l}3 \quad \text { months: } \quad 77 \text { survey } \\
\underline{\text { responses }=46.3 \%}\end{array}$} & \multicolumn{2}{|c|}{$\begin{array}{l}6 \text { months: } 93 \text { survey } \\
\text { responses }=56 \%\end{array}$} \\
\hline & Baseline & 3 months & Baseline & 6 months \\
\hline VAS pain, $(0-100)(\mathrm{mm})$ & $54.7 \pm 15.7$ & $\begin{array}{l}46.1 \pm 23.3 \\
(p=0.02)\end{array}$ & $45.8 \pm 24.8$ & $\begin{array}{l}43.2 \pm 24.5 \\
(p=0.45)\end{array}$ \\
\hline Lequesne index & $9.7 \pm 4.2$ & $\begin{array}{l}8.3 \pm 3.5 \\
(p=0.01)\end{array}$ & $12.4 \pm 13.2$ & $\begin{array}{l}8.3 \pm 4.4 \\
(p=0.008)\end{array}$ \\
\hline KOOS index & $53.7 \pm 16.4$ & $\begin{array}{l}60.2 \pm 17.9 \\
(p=0.03)\end{array}$ & $55.3 \pm 18.0$ & $\begin{array}{l}62.7 \pm 20.1 \\
(p=0.003)\end{array}$ \\
\hline Self-defined improvement & & $n=55(71.4 \%)$ & & $\mathrm{n}=72(78.3 \%)$ \\
\hline Responders $^{\mathrm{a}}$ & & $n=35(45.4 \%)$ & & $\mathrm{n}=51(54.8 \%)$ \\
\hline
\end{tabular}

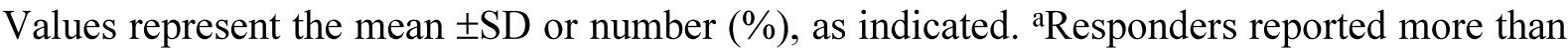
$50 \%$ improvement in the global VAS; VAS= visual analogic score; KOOS=Knee Injury and Osteoarthritis Outcome Score

\section{References}

1. Maheu E, Bannuru RR, Herrero-Beaumont G, et al. Why we should definitely include intraarticular hyaluronic acid as a therapeutic option in the management of knee osteoarthritis: Results of an extensive critical literature. Semin Arthritis Rheum 2018 Jun 19. 
2. Bedard NA, DeMik DE, Glass NA, et al. Impact of Clinical Practice Guidelines on Use of Intra-Articular Hyaluronic Acid and Corticosteroid Injections for Knee Osteoarthritis. J Bone Joint Surg Am. 2018 May 16;100(10):827-834

3. Roos EM, Roos HP, Lohmander LS, et al. Knee Injury and Osteoarthritis Outcome Score (KOOS)--development of a self-administered outcome measure. J Orthop Sports Phys Ther. 1998;28:88-96. 